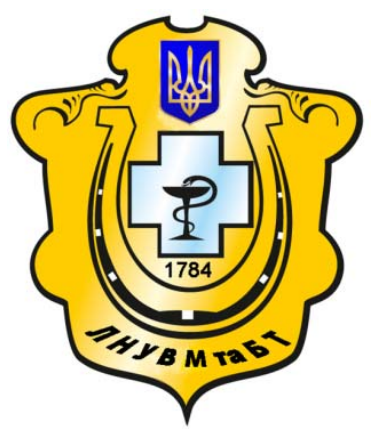

Науковий вісник Львівського національного університету ветеринарної медицини та біотехнологій імені С.3. Гжицького

Scientific Messenger of Lviv National University of Veterinary Medicine and Biotechnologies named after S.Z. Gzhytskyj

doi:10.15421/nvlvet7518

ISSN 2519-268X print

ISSN 2518-1327 online

$\underline{\text { http://nvlvet.com.ua/ }}$

УДК 543.42:664.8

\title{
Розробка рецептур м'ясних паштетів з використанням білково-жирових емульсій на основі вітамінізованих купажованих рослинних олій
}

\author{
Є.О. Котляр ${ }^{1}$, О.А. Топчій ${ }^{2}$ \\ evgenyj11@mail.ru, oksanatopchiy@ukr.net \\ ${ }^{1}$ Одеська національна академія харчових технологій, \\ вул. Канатна, 112, м. Одеса, 65039, Украӥна; \\ ${ }^{2}$ Національний університет харчових технологій, \\ вул. Володимирська, 68, м. Київ, 01601, Україна
}

\begin{abstract}
У статті розглянута розробка рецептур м'ясних паштетів з використанням білково-жирових емульсій (БЖЕ) на основі вітамінізованих купажсованих рослинних олій (ВКРО). Досліджено органолептичні, фізико-хімічні та функиіональнотехнологічні показники нових рецептур м'ясних паштетів з метою збагачення біологічно активними компонентами. $B$ проиесі роботи було створено вісім рецептур паштетів з м'яса птиці зі використанням розроблених БЖЕ, щчо входили до складу рецептури в кількості $15 . .20 \%$ та дві рецептури з вітамінізованими купажованими рослинними оліями двокомпонентного та трикомпонентного складів у кількості 10\%. Контролем були зразки паштетів, виготовлені згідно 3 ДСТУ 4432:2005, які містили 10\% свинячого шпику. Як основну сировину в рецептурах паштетів використовували куряче та індчче м'ясо (попередньо бланшоване), печінку курячу (попередньо бланшовану), яйчя курячі. Дана сировина забезпечує дієтичність продукту, збалансовує вироби за амінокислотним складом. Також в реиептуру дослідних зразків входили такі інгредієнти, як морква та ичибуля пасеровані, манка, хліб пшеничний (попередньо гідратований). Внесення розроблених ВКРО та БЖЕ на їх основі дозволяе збалансувати продукт за жирнокислотним та вітамінним складом. Вивчено також зміни структурно-механічних властивостей у готовому продукті при заміні в ньому шпику на БЖЕ. Проведено ряд мікробіологічних випробувань, а саме: визначення кількості мезофільних аеробних та факультативно-анаеробних мікроорганізмів (МАФАнМ), бактерій групи кишкової палички (БГКП), сульфітредукувальних клостридій, Staphylococcus aureus, L.Monocytogenes ma Salmonella. Подовжено термін зберігання м'ясних паштетів у 2 рази (48 год), тимчасом як за ДСТУ 4432:2005 - 24 год. Технологія купажування рослинних олій розроблена і впроваджена на Одеському заводі кісточкових та рослинних олій, ТОВ «АВА», (акт від 26.03 .2015 р.). Апробацію проведено на виробничих площах ТОВ «Зернопром», де виготовлено пробну партію м'ясних паштетів з використанням білково-жсирових емульсій, створених на основі вітамінізованих купажованих рослинних олій (акт від 18.03 .2016 р.).

Ключові слова: рецептури, розробка, м'ясні паштети, технологія, консистенція, вітамінізовані купажовані рослинні оліі, білково-жирові емульсії.
\end{abstract}

\section{Разработка рецептур мясных паштетов с использованием белково-жировых емульсий на основе витаминизированных купажированных растительных масел}

\author{
Е.А. Котляр ${ }^{1}$, О.А. Топчий ${ }^{2}$ \\ evgenyj11@mail.ru, oksanatopchiy@ukr.net
}

${ }^{1}$ Одесская национальная академия пищевых технологий, ул. Канатная, 112, г. Одесса, 65039, Украина;

${ }^{2}$ Национальный университет пищевых технологий, ул. Владимирская, 68, г. Киев, 01601, Украина

Citation:

Kotlyar, Y., Topchiy, O. (2017). Development of recipeurs of meat pieces with the use of protein-fatty emulsions based on vitaminized blended vegetable oils. Scientific Messenger LNUVMBT named after S.Z. Gzhytskyj, 19(75), 89-96. 
В статье рассмотрена разработка рецептур мясных паштетов с использованием белково-жировых эмульсий (БЖЭ) на основе витаминизированных купажированных растительных масел (ВКРМ). Исследовань органолептические, физикохимические и функционально-технологические показатели новых рецептур мясных паштетов с целью обогащения биологически активными компонентами. В процессе работы было создано восемь рецептур паштетов из мяса птиць с использованием разработанных БЖЭ, входивиих в состав рецептуры в количестве 15 ... $20 \%$ и две рецептуры с витаминизированными купажированными растительными маслами двухкомпонентного и трехкомпонентного складов в количестве $10 \%$. Контролем были образцы паштетов, изготовленные по ГОСТ 4432: 2005, содержашие 10\% свиного ипика. В качестве основного сырья в рецептурах паштетов использовали куриное и индюшиное мясо (предварительно бланиированное), печень куриную (предварительно бланшированную), яйца куринье. Данное сырье обеспечивает диетичность продукта, балансирует изделия по аминокислотному составу. Также в рецептуру опытных образиов входили такие ингредиенты, как морковь и лук пассерованные, манка, хлеб пиеничный (предварительно гидратированный). Внесение разработанных ВКРМ и БЖЭ на их основе позволяет сбалансировать продукт по жирнокислотному и витаминному составу. Изучень также изменения структурно-механических свойств в готовом продукте при замене в нем шпика на БЖЭ. Проведен ряд микробиологических испытаний, а именно: определение количества мезофильных аэробных и факультативно-анаэробных микроорганизмов (МАФАнМ), бактерий группь кишечной палочки (БГКП), сульфитредукувальних клостридий, Stарһуlососсия aureus, L.Monocytogenes u Salmonella. Продлен срок хранения мясных паштетов в 2 раза (48 ч), тогда как по ГОСТ 4432: 2005 - 24 ч. Технология купажирования растительных масел разработана и внедрена на Одесском заводе косточковых и растительных масел, ООО «АВА», (акт от 26.03.2015 г.). Апробацию проведено на производственных площчадях ООО «Зернопром», где изготовлено пробную партию мясных паштетов с использованием белково-жировых эмульсий, созданньх на основе витаминизированных купажированных растительных масел (акт от 18.03.2016 г.).

Ключевые слова: рецептуры, разработка, мясные паштеты, технология, консистенция, витаминизированные купажированные растительные масла, белково-жировые эмульсии.

\title{
Development of recipeurs of meat pieces with the use of protein-fatty emulsions based on vitaminized blended vegetable oils
}

\author{
Y. Kotlyar ${ }^{1}$, O. Topchiy ${ }^{2}$ \\ evgenyj11@mail.ru, oksanatopchiy@ukr.net \\ ${ }^{1}$ Odessa National Academy of Food Technologies, \\ Kanatnaya Str., 112, Odessa, 65039, Ukraine; \\ ${ }^{2}$ National University of Food Technologies, \\ Vladimirskaya Str., 68, Kyiv, 01601, Ukraine
}

The article deals with the development of recipes using meat pates and fat emulsions (BJE) based on vitaminized blended vegetable oils. The organoleptic, physico-chemical and functional and technological characteristics of new formulations meat pates were studied in order to enrich bioactive components. In the process, eight recipes with poultry pastes were created using BJE which were part of the formulation of $15 \ldots 20 \%$ and two formulations of fortified vegetable oils with mixed two-component and three-component formulations in an amount of 10\%. Control samples were pates made under ISO 4432:205, containing 10\% pork bacon. As the main raw material in the formulations, pate chicken and turkey meat (previously blanched), chicken liver (previously blanched), eggs were used. This provides dieteticity of raw product balances by amino acid composition. Also formulation prototypes were such ingredients as carrots, onions and browned, semolina, bread (previously hydrated). Also the changes of the structural and mechanical properties of the finished product when replacing bacon at BJE were studied. A number of microbiological tests have been carried out, namely: the determination of the number of mesophilic aerobic and facultative anaerobic microorganisms (MAFANM), coliform bacteria (SHGP), sulfite-adenocular clostridia, Staphylococcus aureus, L.monocytogenes and Salmonella. The shelf life of meat pates was doubled (48 hours), whereas according to GOST 4432: 2005 - 24 hours.

Quality parameters of meat pates include: organoleptic and structural-mechanical, which were carried out according to wellknown methods, in accordance with existing standards. As a result of the organoleptic evaluation of meat baked pates, it was found that partial replacement of animal fats with vitaminized blended vegetable oils or protein-fat emulsion on their basis generally does not reduce the organoleptic characteristics of the rooted products, and in some cases they are even higher than in the control sample. So, in a control sample, the consistency is dense and the grainspeed, the pates of BJE have a homogeneous pleasant elastic maze-like structure, with their vitaminized blended vegetable oil their consistency is soft and greasy.

Important indicators of food are functional and technological indicators. The change in the pH of the medium affects not only the organoleptic parameters, but also the intensity of the development of the microflora. The putrefactive microflora is capable of multiplying and developing only at $\mathrm{pH}$ of the environment of about 7.0 or higher, and shifting the $\mathrm{pH}$ to the acid side causes a change in the surface structures of the cell, which leads to the formation of conditions unfavorable for its development, and sometimes to destruction and death. Therefore, the pH of the medium is an important factor that affects the quality of the products. Also, when assessing the quality of products, plasticity is taken into account - the product's ability to irreversible deformations.

In a control sample of meat pate, with the addition of animal fat, and meat pates, with the addition of vitaminized blended vegetable oils, a slightly lower content of bound moisture than in the samples with the addition of BJE. This is due to the fact that the composition of BJE includes animal protein, which directly binds the moisture. Considering that heat-treated raw materials are used in the preparation of paste, in which there are no native proteins, the increase in the mass fraction of unbound moisture will soften the consistency of the product. The pH value in the samples with the addition of BJE compared to the control and with the samples supplemented with vitaminized blended vegetable oils vary slightly. The use of vitaminized blended vegetable oils in BJE provides not only the balance of the product with fatty acid and vitamin composition, but also the improvement of technological indicators the increase in the yield of the product after heat treatment. 
The technology of blending of vegetable oils was developed and introduced at the Odessa plant of stone and vegetable oils, OOO AVA, (act from 26.03.2015). Approbation of carrying out on a production area of LLC "Zernoprom», where a trial lot of meat pates is made using protein-fat emulsions created on the basis of vitaminized blended vegetable oils (act from 18.03.2016).

Key words: formulation, development, meat pates, technology, texture, vitaminized blended vegetable oils, protein and fat emulsion.

\section{Вступ}

На сьогодні розв’язання проблеми здорового харчування є найважливішим та актуальним державним завданням, пов'язаним із соціальною стабільністю суспільства і здоров'ям населення.

Одним із шляхів вирішення цієї проблеми є розробка рецептур харчових продуктів, заснованих на теоpiї функціонального харчування, здатних покрити дефіцит незамінних речовин за рахунок підвищення харчової цінності продуктів внаслідок комбінування компонентів рецептури.

Цільове комбінування рецептурних інгредієнтів забезпечує одержання харчової композиції із заданим хімічним складом. Цей підхід складає основу комплексного використання сировини, основна перевага якого полягає в потенційній можливості взаємного збагачення інгредієнтів, які входять до рецептури за одним чи декількома ессенціальними факторами 3 метою забезпечення найбільш повної відповідності створюваних композицій формулі збалансованого чи адекватного харчування (Shazzo and Kas'janov, 2000; Peshuk and Karpenko, 2005; Buttriss, 2006; JemenezColmenero, 2007).

Створення збалансованих рецептур м'ясних продуктів підвищеної харчової цінності 3 поліпшеним жирнокислотним складом і збагачених жиророзчинними вітамінами можна розглядати як важливі напрямки в сучасному харчуванні, що сприяють розвитку ряду суміжних галузей м'ясопереробної промисловості.

Промислове виробництво продуктів харчування, у тому числі продуктів здорового харчування, неможливе в даний час без застосування харчових мікроінгредієнтів: харчових і біологічно активних добавок. Розвиток харчової індустрії визначає асортимент, технологію внесення харчових інгредієнтів, а також справляє величезний вплив на прогресивні процеси в технології продуктів харчування (Chung-Yen et al., 2006; Topchij et al., 2013).

Дослідження вітчизняних і зарубіжних вчених показують, що велику цінність для організму людини ставовлять поліненасичені жирні кислоти (ПНЖК), що містяться в рослинних оліях. Унікальний спектр їх функціональних ефектів зумовив широкий діапазон для застосування. Встановлена стимулююча роль ПНЖК щодо захисних механізмів організму i, зокрема, в підвищенні його стійкості до інфекційних захворювань (Shazzo and Kas'janov, 2000; Peshuk and Karpenko, 2005; Buttriss, 2006; Chung-Yen et al., 2006; Jemenez-Colmenero, 2007).

Традиційні рецептури м'ясних паштетів оцінюються в основному за органолептичними показниками та енергетичною цінністю, без урахування збалансованості продукту за хімічним складом. Таким чином, існуючі рецептури паштетів на м'ясній основі не зав- жди відповідають нормам адекватного харчування. Створення збалансованих рецептур м'ясних продуктів підвищеної харчової цінності з поліпшеним жирнокислотним складом і збагачених жиророзчинними вітамінами можна розглядати як важливі напрямки в сучасному харчуванні. Одним 3 перспективних напрямків досліджень є удосконалення технологій і розробка рецептур паштетів 3 додаванням вітамінізоаних купажованих олій підвищеної біологічної цінності з метою поліпшення збалансованості амінокислотного та жирнокислотного складів, якісних характеристик готової продукції та підвищення засвоюваності, а також розширення асортименту паштетів (Topchij et al., 2013; Topchij and Kotljar, 2014; Topchij and Kotljar, 2015; Kotljar et al., 2016).

Актуальність теми: На початку третього тисячоліття проблема доцільності збалансованого харчування 3 метою забезпечення якості та подовження тривалості соціально-активного життя набуває дедалі більшої актуальності майже в усіх країнах світу.

Сучасні темпи нарощування обсягів виробництва та розширення асортименту традиційних харчових продуктів лише частково вирішують проблему дефіциту повноцінних білків, поліненасичених жирних кислот, вітамінів та мінеральних речовин, проте не в змозі забезпечити збалансованість раціону за основними поживними речовинами.

Аналіз тенденцій розвитку світового ринку свідчить про щорічне зростання асортименту традиційних харчових продуктів на рівні $2 . .3 \%$, а продуктів для здорового харчування на $40 \ldots 50 \%$. Проте у цьому напрямку вітчизняна галузь суттєво відстає від Японії, Західної Європи, США, де $80 \ldots 90 \%$ населення забезпечено продуктами для адекватного харчування, тимчасом як в Україні їх частка значно менша.

Науковці багатьох країн приділяють велику увагу розробленню нових видів збалансованих за складом продуктів, які б увійшли до щоденного раціону та забезпечили позитивний вплив на організм людини. Проте, враховуючи великі теоретичні та практичні напрацювання науковців, існує необхідність додаткових досліджень у технологіях полікомпонентних м'ясних продуктів щодо впливу інгредієнтів для підвищення біологічної ефективності на фізико-хімічні показники та структурно-механічні властивості готових виробів. М'ясні паштети - це гомогенізовані продукти на основі м'яса i жировмісної сировини, з обмеженим вмістом поліненасичених жирних кислот та жиророзчинних вітамінів, зокрема каротиноїдів і токоферолів, які беруть участь в окисно-відновних реакціях клітин та володіють антиоксидантними властивостями.

У зв'язку з цим своєчасним та перспективним напрямом $є$ розроблення рецептур і удосконалення технології м'ясних паштетів 3 використанням білкових препаратів, рослинних олій та жиророзчинних вітамі- 
нів 3 метою поліпшення збалансованості амінокислотного, жирнокислотного та вітамінного складу і якісних характеристик готових виробів.

Враховуючи вищезазначене, набуває актуальності створення рецептур м'ясних паштетів 3 використанням білково-жирових емульсій на основі вітамінізованих купажованих рослинних олій. Це дозволить скоригувати раціони харчування незамінними нутрієнтами, досягти необхідного співвідношення $\omega-6$ : $\omega-3$ жирних кислот, вітамінів: $\beta$-каротину та токоферолу і розширити асортимент м'ясних виробів збалансованого складу.

Мета $i$ завдання дослідження. Метою роботи $\epsilon$ удосконалення технології м'ясних паштетів, збалансованих за жирнокислотним та вітамінним складом 3 використанням вітамінізованих купажів рослинних олій (ВКРО) та БЖЕ на їх основі.

Завдання підвищення ефективності використання на харчові цілі наявних у країні білкових і жирових ресурсів повинно вирішуватися, в основному, шляхом розробки рецептур нового покоління та створення оригінальних технологій комбінованих м'ясорослинних продуктів 3 гарантованим вмістом білків, жирів, вітамінів, макро- і мікроелементів та інших важливих компонентів.

\section{Матеріали і методи досліджень}

Предметом наших досліджень була технологія м'ясних паштетів збалансованого складу з використанням вітамінізованих купажованих рослинних олій і БЖЕ на їх основі.

Об'єкт досліджень - куряче та індиче м'ясо, дослідні м'ясні системи з їх використанням та готові м'ясні паштети.

У роботі використано аналітичні та експериментальні методи досліджень: фізико-хімічні (для визначення якісного і кількісного складу, функціональнотехнологічних характеристик білкової і жирової сировини), інструментальні (для визначення структурномеханічних властивостей), мікробіологічні (для визначення мікробіологічних показників).

\section{Результати та їх обговорення}

Традиційні рецептури м'ясних паштетів оцінюються в основному за органолептичними показниками та енергетичною цінністю, без урахування збалансованості продукту за хімічним складом. Таким чином, існуючі рецептури паштетів на м'ясній основі не завжди відповідають нормам спеціального харчування, а нові рецептури, наближені за складом до ідеального продукту, ще не освоєні.

Згідно з положеннями ДСТУ 4432:2005 «Паштети м'ясні. Технічні умови», м'ясним паштетом називають вироби пастоподібної консистенції з фаршу, виготовленого з вареної або сирої м'ясної сировини з додаванням жиру, запечені в металевій формі або піддані термічній обробці і розфасовані. Норми зазначеного стандарту поширюються на всі м'ясні паштети, за винятком тих, які випускаються у вигляді консервів. Технологія виробництва паштетів передбачає викори- стання багатьох видів сировини тваринного і рослинного походження, що визначає різноманіття застосовуваних способів обробки. Комбінуючи варіння, бланшування, пасерування, обсмажування, гомогенізацію та інші види термічного і механічного впливів, отримують ніжний однорідний продукт пастоподібної консистенції, що відрізняється приємним смаком, запахом і кольором. Співробітниками Технологічного інституту молока та м'яса Академії аграрних наук розроблена «Технологічна інструкція 3 виробництва паштетів м'ясних до ДСТУ 4432:2005». Вищі сорти паштетів, що випускаються відповідно до зазначеного технічного документу, не передбачають використання як сировини свинячої шкурки, рубця і легень. Сучасній тенденції переважного зростання виробництва харчових продуктів високої і повної кулінарної готовності цілком відповідають різноманітні м'ясні паштети й інші пастоподібні гомогенізовані вироби 3 свинини, яловичини, субпродуктів, м'яса птиці - висококалорійні дрібнодисперсні продукти 3 переважаючим вмістом м'ясної сировини. Найменшими споживачами м'ясної продукції є шестимісячні малюки, для годування яких лікарі-дієтологи рекомендують застосовувати дрібнодисперсні м'ясні пасти, багаті необхідними для росту організму повноцінними білками, жирами, залізом тощо (Shazzo and Kas'janov, 2000).

При розробці рецептур м'ясних паштетів керувались наявністю м'ясної сировинної бази, доступністю i економічною доцільністю використання БЖЕ на основі вітамінізованих купажованих рослинних олій.

В процесі роботи було створено вісім рецептур паштетів з м'яса птиці з використанням розроблених БЖЕ, що входили до складу рецептури в кількості $15 \ldots 20 \%$ та дві рецептури з вітамінізованими купажованими рослинними оліями двокомпонентного та трикомпонентного складів у кількості 10\%. Контролем були зразки паштетів, виготовлені згідно з ДСТУ 4432:2005, які містили 10\% свинячого шпику.

Як основну сировину в рецептурах паштетів використовували куряче та індиче м'ясо (попередньо бланшоване), печінку курячу (попередньо бланшовану), яйця курячі. Дана сировина забезпечує дієтичність продукту, збалансовує вироби за амінокислотним складом. Також в рецептуру дослідних зразків входили такі інгредієнти, як морква та цибуля пасеровані, манка, хліб пшеничний (попередньо гідратований). Внесення розроблених вітамінізованих купажованих рослинних олій та БЖЕ на їх основі дозволяє збалансувати продукт за жирнокислотним та вітамінним складом. В табл. 1 наведені рецептури м'ясних паштетів з використанням ВКРО та БЖЕ на їх основі.

До комплексу показників, які визначають якість м'ясних паштетів, відносять органолептичні показники. До них належать ті параметри якості продукту, які визначають його споживчі властивості, тобто ті властивості, які безпосередньо впливають на органи чуття людини. Найбільш значущі з цих параметрів смак і запах - не піддаються формальному вимірюванню, тому їх визначення проводиться експертним шляхом. 
Рецептури м'ясних паштетів з використанням ВКРО та БЖЕ на їх основі

\begin{tabular}{|c|c|c|c|c|c|c|c|c|c|c|c|}
\hline \multirow[t]{2}{*}{ Сировина } & \multirow{2}{*}{$\begin{array}{c}\text { Контроль } \\
\text { за ДСТУ } \\
4432: 2005\end{array}$} & \multicolumn{10}{|c|}{ Варіант рецептури } \\
\hline & & № 1 & № 2 & № 3 & № 4 & № 5 & № 6 & № 7 & № 8 & № 9 & № 10 \\
\hline 1 & 2 & 3 & 4 & 5 & 6 & 7 & 8 & 9 & 10 & 11 & 12 \\
\hline \multicolumn{12}{|c|}{ Кількість основної сировини, \% на 100 кг } \\
\hline Курятина бланшована & 35 & 36 & 38 & 40 & 41 & 35 & & & & & \\
\hline Індиче м'ясо бланшоване & & & & & & & 36 & 38 & 40 & 41 & 35 \\
\hline Печінка куряча бланшована & \multicolumn{11}{|c|}{13} \\
\hline Свинний шпик & 10 & - & - & - & - & - & - & - & - & - & - \\
\hline ВКРО & - & - & - & - & - & 10 & - & - & - & - & 10 \\
\hline $\begin{array}{l}\text { БЖЕ № } 1 \\
\text { або № } 2\end{array}$ & - & 20 & 18 & 16 & 15 & - & 20 & 18 & 16 & 15 & - \\
\hline Хліб & 10 & 3 & 3 & 3 & 3 & 5 & 3 & 3 & 3 & 3 & 5 \\
\hline Яйця курячі & \multicolumn{11}{|c|}{4} \\
\hline Морква & \multicolumn{11}{|c|}{5} \\
\hline Цибуля & \multicolumn{11}{|c|}{5} \\
\hline Манка & 4 & - & - & - & - & 4 & - & - & - & - & 4 \\
\hline Вода для гідр. & \multicolumn{11}{|c|}{ 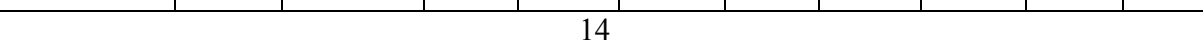 } \\
\hline \multicolumn{12}{|c|}{ Кількість допоміжної сировини, кг на 100 кг основної сировини } \\
\hline Сіль & \multicolumn{11}{|c|}{1,4} \\
\hline Перець & \multirow{2}{*}{\multicolumn{11}{|c|}{$\begin{array}{r}0,05 \\
0,1\end{array}$}} \\
\hline Часник & & & & & & & & & & & \\
\hline Суміш спецій & - & \multicolumn{10}{|c|}{0,1} \\
\hline
\end{tabular}

Основною перевагою органолептичного аналізу як методу оцінки якості продукції є можливість відносно швидкого визначення придатності продукту до споживання. Такі показники, як колір, смак, запах, консистенція дають загальне уявлення про продукт i вказують на правильний вибір основних інгредієнтів та їх співвідношення.

При органолептичній оцінці, під час дегустації зразків, викладачs та студенти кафедри технології м'яса і м'ясних продуктів НУХТ визначили зовнішній вигляд, вигляд на розрізі, консистенцію, колір, смак та запах дослідних м'ясних паштетів. Органолептичну оцінку проводили за п'ятибальною шкалою. Дані органолептичної оцінки наведено на рис. 1.

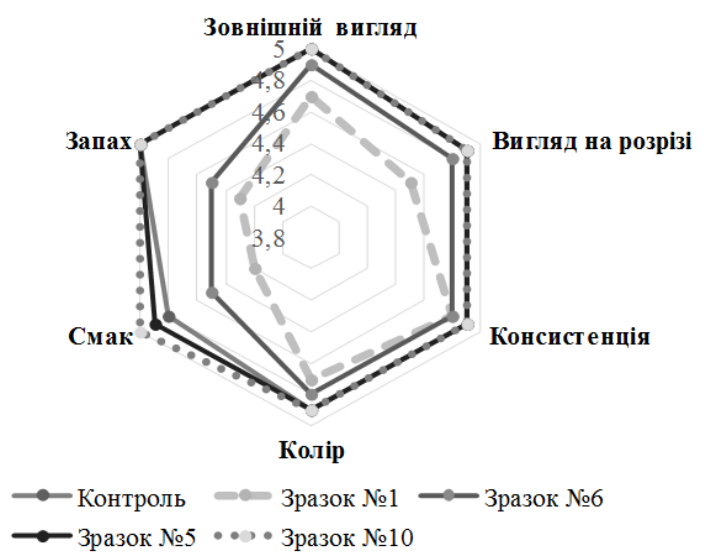

Рис. 1. Органолептична оцінка паштетів м'ясних, запечених з використанням БЖЕ

В результаті проведеної органолептичної оцінки м'ясних запечених паштетів встановлено, що часткова заміна тваринних жирів вітамінізованими купажованими рослинними оліями або білково-жировою емульсією на їх основі в цілому не знижує органолептичних показників розроблених продуктів, а у деяких випадках вони навіть вищі, ніж у контрольному зразку. Так, у контрольному зразку консистенція щільна та крупинчаста, паштети 3 БЖЕ мають однорідну приємну пружну мазеподібну структуру, з вітамінізованою купажованою рослинною олією. консистенція м'яка і мазеподібна.

Отже, можна зробити висновок, що додавання $15 \ldots 20 \%$ БЖЕ або 10\% вітамінізованих купажованих рослинних олій до м'ясних паштетів позитивно впливає на органолептичні показники готового продукту.

Визначення фізико-хімічних та функціональнотехнологічних показників м'ясних паштетів з використанням БЖЕ та ВКРО. Одним із основних показників, який впливає на якість м'ясних паштетів, $є$ загальний хімічний склад.

Тому при розробленні нових видів харчових продуктів, у нашому випадку паштетів м'ясних запечених, важливо дослідити залежність впливу поєднання м'ясної і рослинної (вітамінізованих купажів рослинних олій) сировини в заданому співвідношенні на фізико-хімічні показники продукту. Результати дослідження хімічного складу паштетів наведтно в табл. 2.

Проведені дослідження хімічного складу показали, що м'ясні паштети, виготовлені за розробленими рецептурами, не поступаються контрольному зразку, а заміна тваринного жиру на білково-жирову емульсію не погіршує їх хімічного складу, але зразки № 5, № 10, які містили вітамінізовані купажовані олії, поступаються вмістом білка зразкам № 1, № 6 з БЖЕ.

Оскільки в модельних зразках паштетів замість тваринного жиру, а саме шпику, використовуються БЖЕ та вітамінізовані купажовані рослинні олії, то виникає необхідність дослідити зміни кислотного та пероксидного чисел. Результати досліджень наведено на рис. 2 та рис. 3. 
Хімічний склад м'ясних паштетів

\begin{tabular}{|c|c|c|c|c|}
\hline \multirow{2}{*}{ Зразки рецептур } & \multicolumn{3}{|c|}{ Масова частка, \% } \\
\cline { 2 - 4 } & Волога & Білок & Жир & Зола \\
\hline Контроль за ДСТУ 4432:2005 & $65,0 \pm 0,3$ & $17,4 \pm 0,2$ & $16,6 \pm 0,1$ & $0,95 \pm 0,02$ \\
\hline Рецептура № 1 з БЖЕ & $64,1 \pm 0,3$ & $19,02 \pm 0,2$ & $15,9 \pm 0,2$ & $0,93 \pm 0,02$ \\
\hline Рецептура № 5 3 ВКРО & $63,8 \pm 0,3$ & $19,17 \pm 0,1$ & $16,1 \pm 0,1$ & $0,93 \pm 0,02$ \\
\hline Рецептура № 6 з БЖЕ & $64,0 \pm 0,3$ & $19,1 \pm 0,1$ & $15,9 \pm 0,1$ & $0,94 \pm 0,02$ \\
\hline Рецептура № 10 з ВКРО & $64,0 \pm 0,3$ & $18,80 \pm 0,2$ & $16,3 \pm 0,1$ & $0,94 \pm 0,02$ \\
\hline
\end{tabular}

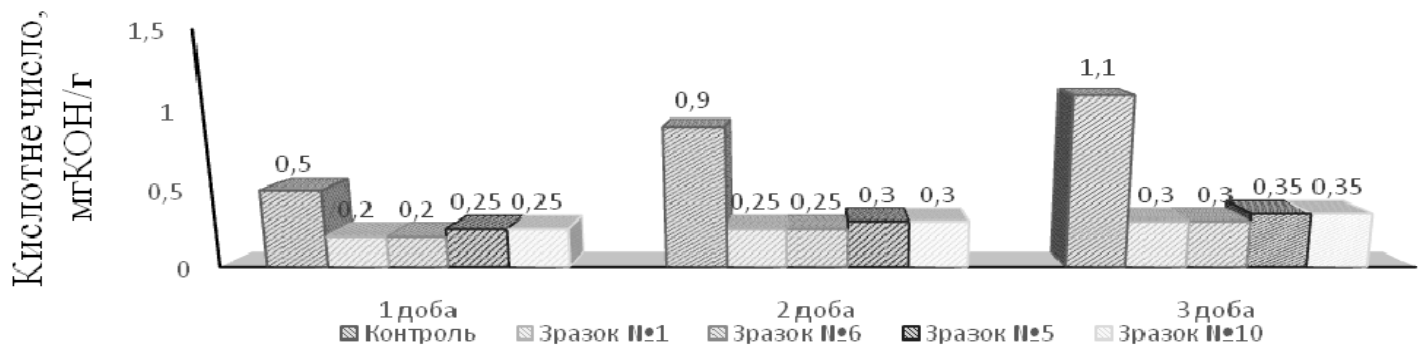

Рис. 2. Зміна кислотного числа в модельних зразках паштетів № 1, № 6 з БЖЕ та № 5, № 10 з ВКРО на третю добу зберігання

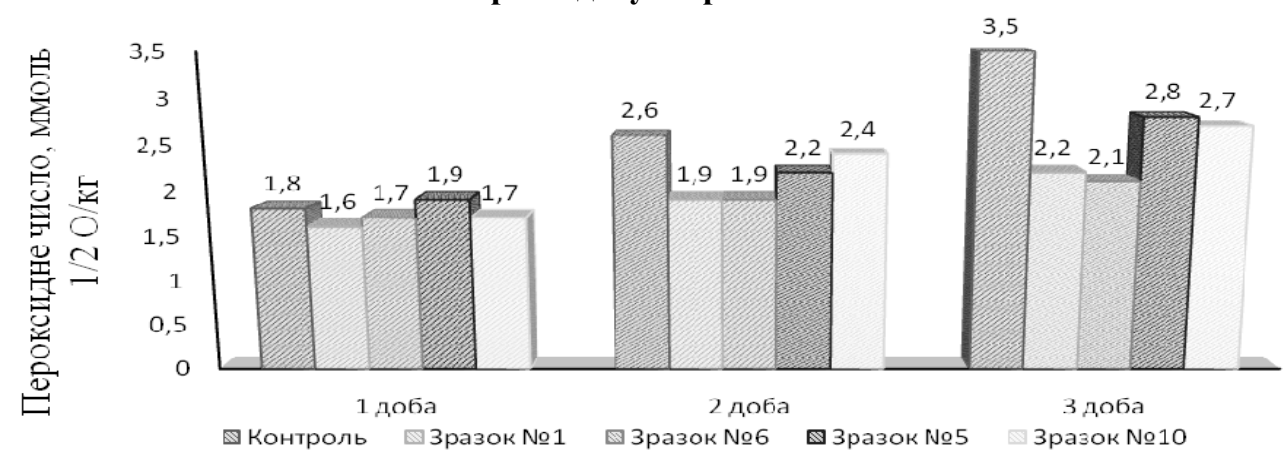

Рис. 3. Зміна пероксидного числа в модельних зразках паштетів № 1, № 6 з БЖЕ та № 5, № 10 з ВКРО на третю добу зберігання

Проаналізуваши дані рис. 2 та рис. 3, можна сказати, що збільшення кислотного і пероксидного чисел в дослідних зразках протікає повільніше, ніж у контрольному. Це пов'язано з тим, що вітамінізовані купажовані рослинні олії та БЖЕ на їх основі мають більшу кількість ненасичених ЖК, ніж шпик, до того ж вони додатково збагачені вітамінами, які проявляють дію антиоксидантів. За результатами досліджень на третю добу можна сказати, що зразки м'ясних паштетів не перевищують норм за пероксидним числом: контроль - 3,5 ммоль $1 / 2 \mathrm{O} /$ кг, № $1-2,2$ ммоль $1 / 2 \mathrm{O} /$ кг, № 6 - 2,1 ммоль ${ }^{1} / 2 \mathrm{O} /$ кг, № 5 - 2,8 ммоль ${ }^{1} / 2 \mathrm{O} /$ кг, № 10 - 2,7 ммоль $1 / 2 \mathrm{O} /$ кг та кислотному числу: контроль 1,1 мг КОН/г, № $1-0,3$ мг КОН/г, № $6-0,3$ мг КОН/г, № 5 - 0,35 мг КОН/г, № $10-0,35$ мг КОН/г, а саме для кислотним числом для зразків з БЖЕ та вітамінізованими купажованими оліями це $1,1 \ldots 1,2$ мг $\mathrm{KOH} / г$, а для шпику 2...2,2 мг КОН/г та пероксидного числа до 10 ммоль ${ }_{2} / 2 \mathrm{O} /$ кг згідно з НТД.

Дослідні зразки з БЖЕ мають кращі показники кислотного і перокисного чисел порівняно 3 контрольним, також варто зазначити: зразки, які мали у своєму складі вітамінізовані купажовані рослинні олії теж поступаються зразкам з БЖЕ пероксидним числом на 0,6 ммоль $1 / 2 \mathrm{O} /$ кг, що ще раз підтверджує доцільність внесення БЖЕ у м'ясні паштети.

За допомогою приладів можна контролювати технологічні параметри сировини і фаршу, якість продукції на будь-якій стадії технологічного процесу виготовлення м'ясного фаршу, а також консистенцію готових виробів.

Білкова система здатна зв'язувати і утримувати вологу. Існує велика кількість різноманітних добавок рослинного і тваринного походження, основною функцією яких є підвищення водозв'язуючої здатності продукту. Важливими показниками продуктів харчування $є$ функціонально-технологічні показники. Зміна $\mathrm{pH}$ середовища впливає не лише на органолептичні показники, а й на інтенсивність розвитку мікрофлори. Гнильна мікрофлора здатна розмножуватись та розвиватись лише при $\mathrm{pH}$ середовища близько 7,0 або вище, а зміщення $\mathrm{pH}$ в кислий бік спричиняє зміну поверхневих структур клітини, що призводить до утворення умов, несприятливих для іï розвитку, а інколи й до руйнування та відмирання. Тому показник $\mathrm{pH}$ середовища є суттєвим фактором, який впливає на якість продуктів. Також при оцінці якості продуктів враховують пластичність - здатність продукту до незворотних деформацій. В таблиці 3 наведені функціонально-технологічні показники термооброблених паштетних мас. 
Функціонально-технологічні показники термооброблених паштетних мас

\begin{tabular}{|c|c|c|c|c|}
\hline Зразки рецептур & $\mathrm{pH}$ & $\begin{array}{c}\text { Вміст зв’язаної вологи, \% до } \\
\text { загальної вологи }\end{array}$ & Пластичність \\
\hline Контроль & $7,20 \pm 0,06$ & $91,50 \pm 1,31$ & $10,00 \pm 0,30$ & 90,80 \\
\hline Рецептура № 1 з БЖЕ & $7,10 \pm 0,06$ & $90,88 \pm 1,26$ & $7,80 \pm 0,30$ \\
\hline Рецептура № 5 3 ВКРО & $7,00 \pm 0,06$ & $88,83 \pm 1,20$ & $13,20 \pm 0,30$ & 98,80 \\
\hline Рецептура № 6 з БЖЕ & $7,10 \pm 0,05$ & $91,09 \pm 1,35$ & $8,40 \pm 0,30$ \\
\hline Рецептура № 10 з ВКРО & $7,05 \pm 0,06$ & $88,73 \pm 1,29$ & $12,50 \pm 0,30$ & 99,40 \\
\hline
\end{tabular}

Як видно 3 табл. 3, у контрольному зразку м'ясного паштету 3 додаванням тваринного жиру та м'ясних паштетах із додаванням вітамінізованих купажованих рослинних олій дещо менший вміст зв'язаної вологи, ніж у зразків з додаванням БЖЕ. Це зумовлено тим, що до складу БЖЕ входить тваринний білок, який безпосередньо зв'язує вологу. Враховуючи те, що при приготуванні паштетних мас використовується термооброблена сировина, в якій вже немає нативних білків, зростання масової частки незв'язаної вологи буде пом'якшувати консистенцію продукту (табл. 3). Значення $\mathrm{pH}$ у зразках $з$ додаванням БЖЕ порівняно 3 контрольним і зі зразками $з$ додаванням вітамінізованих купажованих рослинних олій змінюються незначно.
Використання вітамінізованих купажованих рослинних олій у складі БЖЕ забезпечує не лише збалансованість продукту за жирнокислотним складом, а й поліпшення технологічних показників - зростання виходу продукту після термообробки. При порівнянні 3 контролем, вихід у зразка № 1 збільшується на 4\%, у зразка № 6 - на 3,8\%. Внесення неемульгованих ВКРО, навпаки, зменшують вихід.

Оскільки в рецептури дослідних зразків паштетів входять $15 \ldots 20 \%$ БЖЕ або 10\% вітамінізованої купажованої рослинної олії, було доцільним визначити емульгуючу здатність та стійкість отриманих емульсій і порівняти їх $з$ контролем (з додаванням свинячого шпику). Результати досліджень наведені на рис. 4.

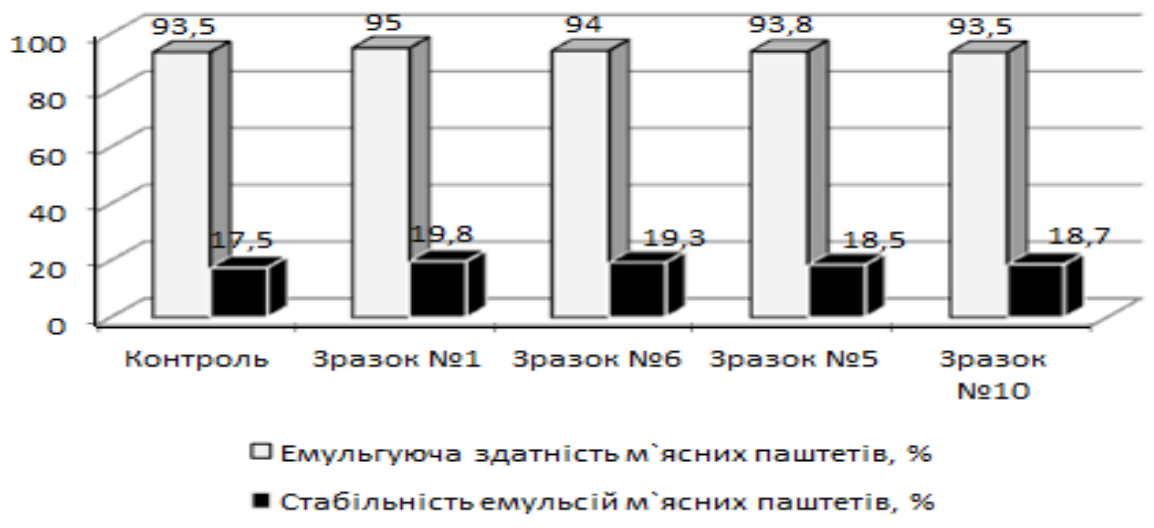

Рис. 4. Емульгуюча здатність та стабільність емульсій м'ясних паштетів

Аналіз даних графічних залежностей свідчить, що емульгуюча здатність контрольного зразка м'ясного паштету менша, ніж у деяких дослідних зразків. Якщо ж порівнювати дослідні зразки між собою, то слід зазначити, що внесення в паштетну масу БЖЕ, до складу якої входить тваринний білок, забезпечує зростання емульгуючої здатності до 95\% (зразок № 1).

При визначенні стійкості емульсій було встановлено: рецептури $з$ додаванням БЖЕ мали кращі результати порівняно з контрольним зразком та зразками, до складу яких входили вітамінізовані купажовані рослинні олії, що підтверджує попередні припущення.

Запечені м'ясні паштети зазвичай споживають без додаткового теплового оброблення. Тому до цих продуктів і до технологічного процесу їх виготовлення пред'являють підвищені санітарні вимоги. Як правило, при виготовленні цих м'ясопродуктів вміст мікроорганізмів порівняно з їх первинною кількістю збільшується.

Сучасні принципи створення високоякісних хар- чових продуктів засновані на виборі та обгрунтуванні певних видів сировини у таких співвідношеннях, які б забезпечували прогнозовану якість, споживні й функціональні властивості та максимальну збалансованість харчових компонентів за хімічним складом готової продукції.

Під час запікання м'ясних паштетів (до досягнення температури $72 \pm 2{ }^{\circ} \mathrm{C}$ ) вміст мікроорганізмів зменшується на 90...99\%. Зберігаються зазвичай спороносні палички i найстійкіші мікрококи. Можуть зберігатися і деякі токсинотворні бактерії.

Залишкової мікрофлори тим більше, чим більше містилося мікроорганізмів в пашетному м'ясному фарші до теплової обробки. У м'ясних паштетах 3 високим вмістом жиру виживає більше бактерій, оскільки жир створює захисну зону навколо їх клітин.

Після запікання паштети м'ясні швидко охолоджують, щоб уникнути розмноження в них залишкової мікрофлори.

При зберіганні цих продуктів відбувається вто- 
ринне інфікування поверхні та поступове збільшення числа бактерій. Чисельність мікрофлори зростає тим швидше, чим вищі температура зберігання і відносна вологість повітря.

Тому було проведено низку мікробіологічних випробувань, а саме: визначення кількості мезофільних аеробних та факультативно-анаеробних мікроорганіз- мів (МАФАнМ), бактерій групи кишкової палички (БГКП), сульфітредукувальних клостридій, Staphylococcus aureus, L.Monocytogenes та Salmonella. Випробування проводилися на базі лабораторії кафедри біохімії, мікробіології та фізіології харчування Одеської національної академії харчових технологій. Результати подано в табл. 4.

Таблицяя 4

Мікробіологічні дослідження зразка м’ясного паштету № 1

\begin{tabular}{|c|c|c|c|c|}
\hline \multirow{3}{*}{$\begin{array}{c}\text { Назва показників, що визначаються } \\
\text { ДСТУ 4432:2005 }\end{array}$} & \multicolumn{4}{|c|}{ Значення показників } \\
\hline & \multirow{2}{*}{$\begin{array}{l}\text { Відповідно до вимог } \\
\text { ДСТУ 4432:2005 }\end{array}$} & \multicolumn{3}{|c|}{ Отримані значення, діб } \\
\hline & & 1 & 3 & 5 \\
\hline МАФАнМ & $1,0 * 10^{3}$ & $1,3 * 10^{2}$ & $2,8 * 10^{2}$ & $1,3 * 10^{3}$ \\
\hline БГКП & Не допускається & \multicolumn{3}{|c|}{ Не виявлено } \\
\hline $\begin{array}{l}\text { Сульфітредуку-вальні клостридії в 0,1 г } \\
\text { продукту }\end{array}$ & Не дозволено & \multicolumn{3}{|c|}{ Не виявлено } \\
\hline Staphylococcus aureus в 1 г продукту & Не дозволено & \multicolumn{3}{|c|}{ Не виявлено } \\
\hline L. Monocytogenes в 25 г продукту & Не дозволено & \multicolumn{3}{|c|}{ Не виявлено } \\
\hline Salmonella в 25 г продукту & Не дозволено & \multicolumn{3}{|c|}{ Не виявлено } \\
\hline
\end{tabular}

Як свідчать показники мікробіологічних досліджень розробленого зразка м’ясного паштету №1, МАФАнМ на третю добу становить $2,8 \times 10^{2}$ КУО при допустимій нормі 1,0×10 КУО. Попередні дослідження КЧ та ПЧ в цьому ж зразку доводять, що на третю добу зберігання вони також перебувають в допустимих показниках. Все це підтверджує безпечність продукту та подовжує термін його зберігання у 2 рази (48 год), тимчасом як за ДСТУ 4432:2005 - 24 год.

\section{Висновки}

Розроблено 8 рецептур м'ясних запечених паштетів з частковою заміною тваринних жирів на БЖЕ на основі ВКРО в кількості $15 \ldots 20 \%$ та 2 рецептури 3 ВКРО двокомпонентного та трикомпонентного складів у кількості 10\%. Розроблені паштети характеризуються високою харчовою цінністю та сприяють оптимізації хімічного складу раціону харчування (за рахунок вмісту вітамінів-антиоксидантів, ПНЖК, білків, мікроелементів). Заміна жирової сировини на БЖЕ не знижує органолептичних показників продуктів, а у деяких випадках вони навіть вищі, ніж у контрольних зразках, також збільшується термін зберігання продуктів за рахунок зниження швидкості протікання окиснювальних процесів.

Перспективи подальших досліджень. У зв'язку з тим, що рослинні олії складаються переважно з легкоокиснюваних ненасичених жирних кислот, то буде перспективною перевірка їх збереження в готових паштетах, що пройшли термообробку до $72{ }^{\circ} \mathrm{C}$ у центрі виробу.

\section{Бібліографічні посилання}

Peshuk, L.V., Karpenko, O.P. (2005). Perspektyva rozrobky special'nyh produktiv harchuvannja na m'jasnij osnovi. Mjasnoj byznes. 2, 14-15 (in Ukrainian).

Zakon Ukrai'ny pro jakist' ta bezpeku harchovyh produktiv i prodovol'choi' syrovyny zi zminamy. www.zps.com.ua. 2005.
Shazzo, R.I., Kas'janov, G.I. (2000). Funkcional'nye produkty pitanija. M.: Kolos (in Russian).

Jemenez-Colmenero, F. (2007). Healthiner Lipid formulation approaches in meat - based functional foods. Technogical options for, replacement of meat fats by non-meat fats. Trends Food Sci. and Technol. 18, 567-578.

Buttriss, J. (2006). Hanging on the coat tails of the obesity epidemic: will metabolic syndrome be the next public health crisis and does nutrition have a role in its prevention? J. Sci. Food Agricul. 86, 2285-2289.

Chung-Yen, C., Lapsley, K., Blumberg, J. (2006). A nutrition and health perspective on almonds. J. Sci. Food Agricul. 86, 2245-2250.

Topchij, O.A., Kyshen'ko, I.I., Kotljar, Je.O. (2013). Vykorystannja roslynnyh olij u recepturah m'jasnyh pashtetiv. Naukovyj visnyk L'vivs'kogo Nacional'nogo universytetu veterynarnoi' medycyny ta biotehnologij imeni S.Z. G'zhyc'kogo. 15, 1(55). 169-173 (in Ukrainian).

Kotljar, Je.O., Goncharenko, T.Ju., Topchij, O.A. (2016). Development of formulation multicomponent proteinfat emulsion (Rozrobka receptur bagatokomponentnyh bilkovo-zhyrovyh emul'sij). Harchova nauka i tehnologija. 4(10), 25-30 (in Ukrainian).

Topchij, O.A., Kotljar, Je.O. (2014). Harakterystyka vitaminizovanyh kupazhiv roslynnyh olij. Harchova nauka i tehnologija. 4(29), 93-97 (in Ukrainian).

Topchij, O.A., Kotljar, Je.O. (2015). Pryncypy kupazhuvannja roslynnyh olij, zbalansovanyh za zhyrnokyslotnym skladom. Shidno-jevropejs'kyj zhurnal peredovyh tehnologij. 1/6 (73), 26-32 (in Ukrainian).

Topchij, O.A., Kotljar, Je.O. (2015). Technological aspects of fortification of blended vegetable oils (Tehnologichni aspekty vitaminizovanyh kupazhiv roslynnyh olij). Vostochno-Evropejskyj Nauchnyj Zhurnal East European Scientific Journal. 1(5), 40-46 (in Russian).

Стаття надійшла до редакиії 10.02.2017 